\title{
Is Technology Based Note-Taking More Preferable For Millenial Students? Exploration Of English Students' Note-Taking Habit
}

\author{
Muhimatul Murtafi’ah, muhimpio98@gmail.com, UINSA (English Language Education \\ Department, Faculty of Education and Teacher Training, Surabaya, Indonesia) \\ Siti Asmiyah, siti.asmiyah @uinsby.ac.id, UINSA (English Language Education
Department, Faculty of Education and Teacher Training, Surabaya, Indonesia)
}

Fitriah, fitriahasad@yahoo.com, UINSA (English Language Education Department, Faculty of Education and Teacher Training, Surabaya, Indonesia)

\begin{abstract}
Note-taking is one of important skills students need to practice in order to understand the content of both printed and unprinted texts effectively. To do note-taking, readers can do either manually or digitally. However, with the advancement of technology nowadays especially in this pandemic era, readers can practice note-taking more easily with the use of technological tools, such as laptop and mobile. This descriptive qualitative research aims to discover how university students practice note-taking particularly to explore their note-taking strategy and preference for refining literature review in English academic writing. This included identifying the strategy they apply in note-taking practices to understand the content of the articles they read and identifying their note-taking. To explore the issue, the researcher collected data through questionnaires and interview with 62 English students taking academic writing who have intense note-taking practices as part of the course activities. The results of this study showed the majority of millennial students prefer using digital note-taking with $66.12 \%$ responses. They decided to use it as it is faster and easier in doing note-taking. The digital technology that the students used commonly was mobile phone with $54.84 \%$ responses. They chose this tool to practice note-taking as it is handy.
\end{abstract}

Key words: Note-taking strategy; Academic Writing; Millennial Students

\section{A. INTRODUCTION}

Note-taking is one of the students' learning techniques or strategies which are popular since the 1980s. According to Dewitt, (2007) cited in Bahrami \& Nosratzadeh, (2017) notetaking is a newsflash about material that should be kept in mind. In teaching and learning, most students carry out note-taking. They may think that note-taking practice is important to understand the point of the teachers' explanation and the content of the book they read. They can take a fancy of note-taking because they assume by taking notes they will get easy to review the material for preparing the test or examination.

Note-taking has some benefits for the students such as their learning can be enhanced by an effective note-taking (Williams \& Eggert, 2002) cited in (Bahrami \& Nosratzadeh, 2017). It means that students can summarize the point that they had heard or read and build their high order thinking. Another benefit of note-taking is students can perform better in understanding teachers' idea than students who only listen to the teachers' explanation (Witrock, 1974) cited in (Luo et al., 2018). In other words, students who take notes will understand the teachers' point better instead of students who only listen to the teachers' explanation without having any prior 
knowledge and notes. Stacy and Cain, (2015) which cited in Mfaume et al., (2018) believe that note-taking is the crucial activity for the students who have no precious listening and notetaking skills to enhance them to be competent practitioner. This activity helps capture understanding and point from some sources (Puput Arianto, 2017). It is common to practice note-taking during lecture and reading text book (Mosleh \& Baba, 2013).

Several studies identified the positive effect of note-taking on students' language skills. For example, note-taking could support students in their learning and improve their writing (Boch \& Piolat, 2005). Ahour \& Bargool, (2015) identified that note-taking could facilitate students' listening comprehension. One of note-taking strategy that Biria, (2010) found was Cornell note-taking. Biria, (2010) identified that Cornell Note-taking could support the students to enhance their reaching. However, Jansen, R.S. (2017) says that note taking is not always beneficial. It depends on the teacher, how the teacher teach their students to take notes. This is because every student has different ability in taking notes and one strategy does not always work well for all students. DeZure et al., (2001) argue that note-taking demands a set of skills in grasping important points and the interaction between students and teacher.

In the 1980s, people did note-taking manually or traditionally with the use of a book and pen or pencil (Luo et al., 2018). There are two ways in practicing note-taking. Traditional strategy and Technology-based strategy (Mosleh \& Baba, 2013). Traditional strategy is a manual notetaking with the use of a paper and pen. In traditional strategy, there are eight methods of notetaking. Those methods are Two Column method, Cornell method, REAP Method, Outline Method, Mapping Method, Charting Method, Sentence Method and the Main Map Method. Two Column Method is dividing the paper into two columns so students can put different information in each column. The Cornell method is the systematic note-taking method. According to Mosleh \& Baba, (2013) Cornell Method defines the paper into three columns. Left column is for writing the key word; right side is for writing the notes and the elaboration of the key points; and the bottom part is for writing the summary or conclusion. Anjarsit et al, (2017) discovered that Cornell can assist the students in creating a good and effective notetaking. Another traditional strategy is REAP Method. This method is similar to Cornel Method which divides the paper into three columns. The Three Columns on REAP strategy have different functions such as writing down the situation or the event, writing down the point and the connect information, and elaborating point and attaching the picture (Mosleh \& Baba, 2013). Outline Method arranges the information from the general to more specific information. This method is different from other methods because the information or the point inform of question. Next method is mapping which uses graphic to represent the information. When using this method, the students can be more active and critical on writing the information. Charting Method is another note-taking strategy; it is noting process while listening to the speech or presentation of the history etc. The column is used for noting the elaboration of the topic and classified based on the column. The information that noting in this method can be in form of word, phrase, and main idea. Sentence Method does not need to plan notes; students write all facts, information and ideas in a certain line and form of sentence. The last strategy is Main Map Method. This method is considered new note taking practice, and it is assumed as an effective way in building students' critical thinking.

In technology- based note-taking strategy or digital strategy, there are nine methods. Six of them are similar to traditional note-taking (e.g. Cornell Method, Two Column Method, Charting Method, Outlining Method, Mapping Method and Sentence Method) but the way the students do note-taking is with the assistance of technology. The other three that cannot be applied manually are Coloring Method, Symbols or Underlining Method, and Apps Method. Coloring Method refers to highlighting the sentence or main points of the paragraph with 
different colours to relate and compare to different information. Coloring Method can help students trigger their memory when reviewing the material. Another digital strategy is Symbols or Underlining Method. It uses symbols to highlight the important information that students want to emphasize. The last is apps method; there are lot of note-taking apps available for students to use with their laptop and mobile, for example Coggle, Evernote, Google Drive, Liquid Text, MindMeister, and Padlet. Stacy \& Cain, (2015) argue that most of students may elect to use technology tools rather than traditional way as typing the notes will be more legible than writing with hand. It is also faster to do note-taking through mobile than pencil-paper. However, Jansen, (2017) argues that the most common of note-taking strategy is hand writing and typing through computer.

The study of note-taking practice was popular around 2015 to 2019. Most studies identified the effectives of note-taking on reading and listening comprehension found that notetaking could facilitate reading comprehension effectively. (Bahrami \& Nosratzadeh, 2017) Students can take notes while reading a book. The note is effective in reminding the students to the material they read. Another research found that SOAR (Select, Organize, Associate, and Regulate) strategy was effective in reviewing material (Kiewra et al., 2018). As discussed at the outset, many previous studies of note-taking practices focused on identifying effectiveness of note taking on reading and listening and the strategies in improving note-taking. The research of note-taking in refining literature review is less. That is why this research investigated the practice of note-taking which focuses on refining literature review. The note-taking differentiate into two, manual note-taking and technology-based note-taking. We decided to include technology based note-taking as technology has been part of human life and students may also use technology in practicing note-taking. The aim of this study is to discover how university students practice note-taking particularly to explore their note-taking strategy and preference for refining literature review in English academic writing. This includes identifying the strategy they apply in note-taking practices and to find out whether most millennial students do notetaking by using technology-based strategy or traditional strategy.

\section{B. METHOD}

Qualitative research method is used in this study. This study identified the strategy and also the types of note-taking used by millennial students during reading the literature review in English academic writing. In addition, this study also identified how millennial students practice note-taking. According to (Rajasekar \& Veerapadran, 2006) qualitative research is a research which concern with the qualitative event include the quality. In the qualitative research, it uses word for explaining and elaborating the data and also in describing the reason of the event. Qualitative research does not use numerical data. The aim of the qualitative research is for showing the feeling, the meaning and describing the condition.

The data of this research are information about the note-taking strategy, the kind of notetaking method used by most of millennial students for doing literature review in English academic writing. For collecting the data, the researcher used questionnaire, and interview. The two instruments were developed based on key aspects of note-taking in existing literature about note-taking strategy such as those are (Luo et al., 2018), (Anjarsit et al., 2017), and (Mosleh \& 
Baba, 2013). The questionnaire and interview technique were used for collecting the data of how millennial students do note-taking and the strategy and method of note-taking used by millennial students. The questionnaire was in three sections; section one is introduction and identities, section two consist of six questions and six additional questions in form of open ended question. The questions were the general information about note-taking such as the importance, the way students do note-taking and the reason. Section three consists of ten close ended questions. The questions were about note-taking methods. Those asked about the type of note-taking method used by most of millennia students.

As the source of the study, the researcher read the previous studies to find out the theory of variety note-taking strategy. However, for the data note-taking strategy used by millennial students were collected from the millennial students through the questionnaire and the interview. The source of most common note-taking strategy and types of note-taking used is millennial students who practicing note-taking for refining literature review in English academic writing class. The millennial students were the 62 colleges of English language education department of UINSA (Universitas Islam Negeri Sunan Ampel Surabaya). For collecting the data, the researcher distributed questionnaire to the 62 college students of UINSA who practicing note-taking for refining literature review and interviewed 4 college students as the representative from the 62 college students.

In analyzing the data there were six steps: The first step of data analysis of interview data was transcript the data from the audio to the written form. The researcher did transcript the data only for the data needed by the researcher to answer the research question. After getting the data, the researcher read all the data from both questionnaire and interview which have been answered by the participants, millennial students. The researcher also read the example or the sample of the students' notes. Moreover, the researcher read the data from the study literature. After reading the data, then researcher highlighted the key point of the answer from the participant that related to the question or usually it is called as coding. The highlighting here means by giving underline for each key point. After coding the data, next is the categorizing the data that have coded before based on the similarities of the data which showed by the color of highlighter. Categorizing was done by giving different color. Red color is for data refers to mobile while green color for data refers to laptop. The other data is yellow color for data refers to note-taking for recall material. After categorizing the data, then the researcher did drawing the conclusion from the data as the result and answer of the questions.

\section{RESULT AND DISCUSSION}

After distributing the questionnaire to 62 students of English Language Education Department (PBI: Prodi Pendidikan Bahasa Inggris) UINSA Surabaya and interviewing 3 students as the sample, almost all students stated note-taking is crucial and benefcial for them in order to help them in learning. There were 79.09\% students argue note-taking is helpful for them for reviewing material and recall their understanding. As student $\mathrm{A}$ had stated in the questionnaire "it is helpful to keep and recall the material we have read and learnt". 
Furthermore, student B added "note-taking gives a better understanding toward the material". From those two students' statement, we can conclude most of students mind note-taking is the crucial thing in the learning process. Note-taking could effects on the students learning. This is in line with (Bahrami \& Nosratzadeh, 2017) note-taking is important because it can help students in remembering what they have read and learnt. This finding implies that as the students presume note-taking is important, they must have done note-taking before and to the future. This aspect is important to know as the reliability for the next aspect that is discovered in this learning, how they do note-taking.

\section{a. The Result of The Importance and The Use of Digital Notes}

No.

1. The importance of note-taking

2. The use of digital note-taking:

3. The use of mobile digital note-taking

4. The use of laptop digital note-taking

\section{Percentages}

$59.7 \%$ students strongly agree, 33.9

$\%$ students agree while the $6.5 \%$ students undecided

$19.4 \%$ students strongly agree, 27.4 $\%$ students agree, $37.1 \%$ students undecided, $14.5 \%$ students disagree and $1.6 \%$ students strongly disagree

From all students who use digital note-taking, there were $54.84 \%$ students use mobile

From all students who use digital note-taking, there were $37.09 \%$ students use laptop

Table 1. Percentage of how students do note-taking

From 62 students, most of them, $59.7 \%$ students stated strongly agree and $33.9 \%$ stated agree on the importance of note-taking, think note-taking is important. As in the questionnaire, student E stated "by doing note-taking, I have the file and document of what I have learnt". Student $\mathrm{C}$ added "it can ease me to learn, recall and understand, the material". Most students argue nota-taking is crucial for them because of its benefit for their learning process. The result of (Boch \& Piolat, 2005) showed that note-taking is important for increasing writing skill. However, this study showed that note-taking is essential for millennial students in order to ease them in recall material and in refining literature review.

In refining literature review, some students decided to use digital note-taking while some others, the most, decided to use both digital and traditional note-taking based on the situation and condition. In the questionnaire, Student C sated "In daring situation, I use digital note-taking by underlining or using apps and sofware in laptop or mobile". Student D addaed "I do digital note-taking but in the learning process, in the class I do traditionally". In using digital note-taking, from the open ended question in the questionnaire, there were $66.12 \%$ students prefer to use digital note-taking because they mind that it make them faster and easier 
to do note-taking by using the apps or platform. This is in line with what (Belson \& Hartmann, 2016) say about digital tools, such as digital pens can improve the and increase the quality of the students' note-taking. Furthermore, from the close ended question of the questionnaire, the result showed that there were $19.4 \%$ students stated strongly agree, $27.4 \%$ agree in using digital tools. There were $37.1 \%$ student stated undecided in using digital tools. It means they did both using digital and traditional tools. However, there were only $14.5 \%$ student stated disagree and $1.4 \%$ students stated strongly disagree in using digital tools while they doing notetaking in refining literature review.

In implementing digital tools as the media or the acquipment for taking notes, There were $54.84 \%$ students decided to use their mobile for taking notes. It is because their mobile is always handy so that they can directly take notes in current situation. (Mfaume et al., 2018) state the popular note-taking tools in the digital era is mobile note-taking, mobile photo notetaking. The other $37.09 \%$ students did note-taking by using laptop because they feel free to type and explore their note taking with big space on the screen. Student A stated "I enjoy doing note-taking using my laptop because it prvides wide screen; my document already there in my laptop". Millennial students applied digital note-taking because it is easy and fast to access. Although the percentage of mobile as media to taking notes is higher than laptop, it still draw the fact that millennial students do note-taking in this digital era using technology.

One of unexpected result is the use of digital note-taking. There are some students do digital note-taking which have only a bit higher percentage than undecided students. There were $19.4 \%$ students strongly agree, $27.4 \%$ students agree in using digital tools. There were $37.1 \%$ students undecided. However, there only $14.5 \%$ students disagree and $1.6 \%$ students strongly disagree. Some more students do digital, some others do both digital and traditional while minority is use traditional note-taking only. It might because the digital tools are not always ready to use such as it not in possible time and condition to use the digital tools. However, there are only a view students do not practice digital note-taking.

\section{b. The Result of the Most Common Note-taking Method}

No. Note-taking Methods

1. Sentense Method

2. Coloring Method

3. Symbol or Underlining Method

\section{Percentages}

$30.6 \%$ strongly agree, $38.7 \%$ agree, $21 \%$ students undecided, $8.1 \%$ students disagree and 1.6 students strongly disagree

$27.4 \%$ strongly agree, $29 \%$ agree, $24.2 \%$ students undecided, $16.1 \%$ students disagree and $3.2 \%$ students strongly disagree

$27.4 \%$ strongly agree, $25.8 \%$ agree, 24.2 $\%$ students undecided, $17.7 \%$ students disagree and $4.8 \%$ students strongly disagree

Table 2. The percentage of the most used note-taking method 
In practicing note-taking, millennial students, students of PBI UINSA Surabaya use some kind of methods. Those methods were Two Column Method, Cornell Method, Outlining Method, Mapping Method, Charting method, Sentence Method, Coloring method, Symbols or underlining methods, Using Apps Method. The most common method used by millennial students is Sentence Method. In Sentence Method, there was the highest percentage of student agreement. From the interview, it showed almost all students applied Sentence Method because this is the simplest way of note-taking. Student A stated "It was the method that usually I use and it is simple does need more tools or platform". The others common method used by millennial students are Coloring Method and Symbol or Underlining Method. More than $50 \%$ students practice Coloring Note-taking. In Coloring Method, there were $29 \%$ students stated agree to use Coloring Method and $27.4 \%$ students stated strongly agree for practicing Coloring Method in order to make their note taking to be good looking and easy. Student E stated "I like to use Coloring Method because it can make my notes be more wonderful and it helps me easier to learnt, each color has meaning". However, in symbol or underlining method, there were 25.8 $\%$ students stated agree in practicing Underlining Method and $27.4 \%$ students stated strongly agree. Students like to do underlining which based on their learning style. It was the students' style and habit of having read books or articles then underlining the key point.

One bold interesting finding from this study is the Sentence Method as the highest percentage, the most common note-taking used by millennial students. One possible factor that might influence this finding is the efficiency of the sentence note-taking. By using Sentence Note-taking, using their own sentences, it might ease students in reread. Reddington et al., (2015) argue that writing is process to express idea in written. Doing note-taking in the form of sentence means that the students express their idea about what they understand in the process reading literature review. The result of their note-taking make them do not need to spend more effort for rereading and understanding the whole material because students already know what they have written. As the three interesting method, those are not only Sentence Method but also Coloring and Underlining Methods. It might because the three methods are easier and more practical rather than other methods such as Cornell, Charting and some other methods. From that, it showed that most millennial students prefer to use practical note-taking strategy.

Another interesting finding in this research is the use of apps as media to do note-taking. This phenomena is in line with the fact that millennial students born in digital era. It also fits the liking of the millennial students' soul with applications which are easy to used and accessible through their gadget. They are used to take a fancy of various digital media to help their daily need, in this case is doing note-taking for refining literature review. This statement is in accordance to what Martin, (2007) says about millennial students use application because of its benefit. It can record the notes for longer time. However, from the result of interview, millennial student use app because it's already there in their mobile or laptop. Furthermore, the template and the feature provided in the application is the solution for students who have difficulties in designing and managing their note.

Moreover, some students also enjoy to use apps or platform in practicing note-taking by using apps which already there on the both mobile and laptop. Some others enjoyed to use specific apps they downloaded from play store. Student A stated "usually I use apps or platform which already there in my mobile and laptop" while student E stated "Sometimes, I download some apps for my specific note-taking from my mobile". Some apps which used by the millennial students are Memo app, Color notes, MIUI notes, Microsoft Word, Notes, Sticky 
notes, Google keep, and WordPad. Wyk \& Ryneveld, (2018) say that the majority students prefer to use applications in taking notes. They might use more than one application for supporting them in creating notes. It depends on their software developers of their mobile.

\section{c. The least used Note-taking Method}

No. Note-taking Methods

1. Cornell Method

2. Charting Method

3. Two Column Method

\section{Percentages}

$4.8 \%$ agree, $8.1 \%$ strongly agree, $41.9 \%$ students undecided, $22.6 \%$ students disagree, $22.6 \%$ students strongly disagree

$19.4 \%$ agree, $8.1 \%$ strongly agree, $38.7 \%$ students undecided, $17.7 \%$ students disagree and $16.1 \%$ students strongly disagree

$17.7 \%$ agree, $11.3 \%$ strongly agree, 32.2 $\%$ students undecided, $22.6 \%$ students disagree and $16.1 \%$ students strongly disagree

Table 3. The percentage of the lest used note-taking method

On the other hand, three the least used method by students are Cornell Method, Two Column Method, and Charting Method. The highest percentage here is by Charting method that showed $17.7 \%$ students agree and $11.3 \%$ students strongly agree for doing Charting Method. This was far from what Sentence Method result which had more than $50 \%$ students practiced Sentence method in doing note-taking. The least percentage came from Cornell Method that showed $4.8 \%$ students agree and $8.1 \%$ students strongly agree to do Cornell Method.

One of the least stood out finding of this research is Cornell Method as the lowest percentage note-taking used by millennial students. There were only view students used this method while they are reading literature review. Factor that might influence this finding is the low students' literacy level. There were only view students know that Cornell Note-taking Method is existed. They are already implemented the Sentence Method when doing note-taking and did not think of using any other method than what they were used to. Other factor, it might because by using Cornell Method its takes more time for the preparation. It also takes more time in practicing note-taking by using this method. Furthermore, it might because most of millennial students are not familiar with the Cornell Method. Because of the low literacy level, the students have limit experience and knowledge about the Cornell Method. Although, the Cornell Method is good for increasing students' learning and notes. Cornell Method gives positive effect on the students' achievement (Alzu'bi, 2018). However, this finding showed that there is only a few students, $4.8 \%$ and $8.1 \%$ students, do Cornell Method.

From the explanation above, the result of this research showed that most of the millennial students practice both traditional and technology-based note-taking. It based on the situation and condition of the students and their needs. In practicing traditional-based note- 
taking, almost all millennial students decided to use their mobile due to the mobile is always being handy. Using mobile as the digital tool, in practicing note-taking for refining literature review, the majority of the millennial students implement sentence, coloring and symbol or underlining method as the most common method used.

\section{CONCLUSION}

To sum up, the result of this study showed almost students practiced digital note-taking. Most students did digital note-taking in order to help them be faster and easier in creating notetaking. In which, digital note-taking can be done through laptop and mobile which are always in hand of most students. So that, students can direct do note-taking through their mobile. By using mobile, the method of digital note-taking which is the most common millennial students did, as the highest percentage is sentence method. The second most common note-taking methods are Coloring and Symbol or Underlining Methods. As the suggestion for the next further researcher to examine the implementation of some other methods, uncommon methods, such as two column method and charting method for the refining the literature review so that students can know the other note-taking method that they can practice. Moreover, it can help students to know other effective note-taking for refining literature review.

From the questionnaire, we can conclude that a bit more students use Technology-based Strategy. Although the majority of approved students use Technology-based strategy with those students who do not select (those who do both Technology-based and Traditional Strategies), the difference is not significant, $39.8 \%$ (include agree and strongly agree) and $37.1 \%$. Furthermore, the difference between the approved and unapproved students is significant, 39.8 $\%$ students and $16.1 \%$. In implementing Technology-based strategy, the most common methods use are Sentence, Coloring and Underlining Methods.

\section{E. REFERENCES}

Ahour, T., \& Bargool, S. (2015). A Comparative Study on the Effects of While Listening Note Taking and Post Listening Summary Writing on Iranian EFL Learners' Listening Comprehension. Theory and Practice in Language Studies, 5(11), 2327. https://doi.org/10.17507/tpls.0511.17

Anjarsit, Y., Adnan, A., \& Padang, U. N. (2017). the Use of Cornell Note Taking Technique To Improve Listening Comprehension of Senior High School Students. Journal of English Language Teaching, 6(1), 9-15. http://ejournal.unp.ac.id/index.php/jelt/article/download/7120/5648

Bahrami, F., \& Nosratzadeh, H. (2017). The Effectiveness of Note-Taking on Reading Comprehension of Iranian EFL Learners. International Journal of Applied Linguistics and English Literature, 6(7), 308. https://doi.org/10.7575/aiac.ijalel.v.6n.7p.308

Belson, S. I., \& Hartmann, D. (2016). Digital Note Taking: The Use of Electronic Pens with Students with Specific Learning Disabilities. June 2013. https://doi.org/10.1177/016264341302800202

Biria, R. (2010). Note-taking Strategies and Academic Achievement. Dil ve Dilbilimi Çalışmaları Dergisi: Uluslararası Çevrimiçi Dergisi, 6(1), 0-109. 
https://doi.org/10.17263/jlls.39297

Boch, F., \& Piolat, A. (2005). Note taking and learning: A summary of research. The WAC Journal, 16(September), 101-113.

DeZure, D., Kaplan, M., \& Deerman, M. A. (2001). Research on Student Notetaking: Implications for Faculty and Graduate Student Instructions. CRLT Occaisional Papers, 16(August), 8.

Kiewra, K. A., Colliot, T., \& Lu, J. (2018). Note This: How to Improve Student Note Taking. IDEA Paper \#73. The IDEA Fund, 73(January), 1-18.

Luo, L., Kiewra, K. A., Flanigan, A. E., \& Peteranetz, M. S. (2018). Laptop Versus Longhand Note Taking: Effects On Lecture Notes And Achievement. Instructional Science, 46(6), 947-971. https://doi.org/10.1007/s11251-018-9458-0

Martin, M. (2007). The Millennial Student: A New Generation of Learners. 2, 42-46.

Mfaume, H., Bilinga, M., \& Mgaya, R. (2018). From paper and pencil to mobile phone photo note-taking among Tanzanian university students: Extent, motives and impact on learning. International Journal of Education and Development Using Information and Communication Technology (IJEDICT), 14(2), 83-98. https://files.eric.ed.gov/fulltext/EJ1190028.pdf

Mosleh, M. a a, \& Baba, M. S. (2013). Overview of Traditional Note Taking. Educational Psychology Review, Cole 2005, 1-28.

Puput Arianto. (2017). English Education: Jurnal Tadris Bahasa Inggris. The Implementation of Note-Taking Strategy in Listening Class, 10(1), 119-134.

Rajasekar, S., \& Veerapadran, C. (2006). Research Methodology. January.

Reddington, L. A., Peverly, S. T., \& Block, C. J. (2015). An examination of some of the cognitive and motivation variables related to gender differences in lecture note-taking. Reading and Writing, 28(8), 1155-1185. https://doi.org/10.1007/s11145-015-9566-Z

Stacy, E. M., \& Cain, J. (2015). Note-taking and handouts in the digital age. American Journal of Pharmaceutical Education, 79(7). https://doi.org/10.5688/ajpe797107

Williams, R. L., \& Eggert, A. C. (2002). Notetaking in College Classes: Student Patterns and Instructional Strategies. The Journal of General Education, 51(3), 173-199. https://doi.org/10.1353/jge.2003.0006

Wyk, M., \& Ryneveld, L. (2018). Affordances of mobile devices and note-taking apps to support cognitively demanding note-taking. 